\title{
Drift algae-epiphyte-seagrass interactions in a subtropical Thalassia testudinum meadow
}

\author{
E. A. Irlandi ${ }^{1,2, *}$, B. A. Orlando ${ }^{1,3}$, P. D. Biber ${ }^{1,4}$ \\ ${ }^{1}$ University of Miami, Rosenstiel School of Marine and Atmospheric Science, Miami, Florida 33149, USA \\ ${ }^{2}$ Present address: Florida Institute of Technology, Department of Marine and Environmental Systems, 150 West University \\ Boulevard, Melbourne, Florida 32901, USA \\ ${ }^{3}$ Present address: South Florida Water Management District, 3301 Gun Club Road, West Palm Beach, Florida 33406, USA \\ ${ }^{4}$ Present address: University of North Carolina at Chapel Hill, Institute of Marine Sciences, 3431 Arendell Street, \\ Morehead City, North Carolina 28557, USA
}

\begin{abstract}
Determination of the percentage cover and residence time of drift algae over permanently marked $0.25 \mathrm{~m}^{2}$ plots at 8 study sites indicated that drift algal cover was relatively low $(<20 \%$ at most sites) and did not remain in the same location longer than 2 to 3 mo. Experimental maintenance of high drift algal cover for 2 to 3 mo produced a ca. $25 \%$ reduction in above-ground biomass compared to plots free of drift algae, but the magnitude of the decline in biomass did not increase with an additional 3 mo of algal cover. Below-ground biomass and shoot density, however, were not affected by the presence of drift algae, suggesting that a change in plant morphometrics contributed to reduced above-ground biomass and limited long-term negative impacts as root reserves were not depleted. We investigated the effects of drift algal cover on short-term growth of Thalassia testudinum at 2 different sites in 2 different seasons. In neither instance did we observe any decrease in growth rates of $T$. testudinum in the presence of drift algae. The lack of a negative effect of drift algae on seagrass growth is likely due to the clonal nature of the seagrass plants, their ability to share resources among shaded and unshaded short shoots, and the availability of stored reserves in robust roots and rhizomes. We also conducted growth experiments assessing the effects of epiphytes on growth of T. testudinum. Unlike drift algal cover, the presence of encrusting calcareous epiphytes was shown to have a negative impact on growth of $T$. testudinum. This is likely due to a combination of decreased light levels as well as a reduction in exchange of materials across the boundary layer at the leaf surface. Collections of seagrass leaves from under drift algae and from areas free of drift algae indicated that filamentous epiphyte loads are decreased in the presence of macroalgae. Our results suggest that temporary, moderate cover of macroalgae may benefit seagrass by reducing epiphyte loads if the epiphyte cover negatively impacts the seagrass.
\end{abstract}

KEY WORDS: Plant/plant interactions $\cdot$ Macroalgae $\cdot$ Seagrass $\cdot$ Epiphytes $\cdot$ Thalassia testudinum

\section{INTRODUCTION}

Submerged aquatic vegetation (SAV) in an estuary is composed of numerous types of primary producers, including rooted angiosperms or seagrasses, attached (including rhizophytic) and drifting forms of macroalgae, and epiphytic algal species living on the blades of seagrass. The epiphyte community can contribute significantly to estimates of overall primary production in seagrass meadows and provide an important food source to grazers (e.g. amphipods and small gastropods) (Klumpp et al. 1992, Neckles et al. 1993, 1994, Pollard \& Kogure 1993, Frankovich \& Zieman 1994, Wear et al. 1999). Epiphytic algae can range from diatoms to encrusting calcareous species to more diminutive filamentous forms of macroalgae (Humm 1964, Harlin 1980, Kendrik and Lavery 2001). Macroalgae also contribute to primary production of the SAV 
community (Fry 1984, Virnstein \& Carbonara 1985, Heijs 1987), and provide additional structure to seagrass meadows and important habitat for numerous estuarine species (Kulczycki et al. 1981, Herrnkind \& Butler 1986, Virnstein \& Howard 1987, Schneider \& Mann 1991, Holmquist 1994).

Seagrass, epiphytes, and macroalgae occur together with their abundances influenced both directly and indirectly by top-down (grazing) and bottom-up (nutrient) controls (e.g. Neckles et al. 1993, 1994, Williams \& Ruckelshaus 1993, McGlathery 1995, Hauxwell et al. 1998, Gacia et al. 1999, Heck et al. 2000). Under enhanced nutrient inputs typical of many coastal estuaries, blooms of epiphytes (Tomasko \& Lapointe 1991, Neckles et al. 1993, Williams \& Ruckelshaus 1993, Coleman \& Burkholder 1994, Frankovich \& Fourqurean 1997, Wear et al. 1999) and/or macroalgae (Lavery et al. 1991, Lapointe et al. 1994, Duarte 1995, Short et al. 1995, Taylor et al. 1995, McGlathery 2001) can occur and proliferations of either can be detrimental to the underlying seagrass (Twilley et al. 1985, Holmquist 1997, Valiela et al. 1997, Hauxwell et al. 2001, McGlathery 2001, Nelson \& Lee 2001).

Preliminary observations, however, of seagrass under mats of drifting macroalgae in a well-flushed, subtropical estuary (Biscayne Bay, FL) revealed vibrant green, epiphyte-free, and apparently healthy leaves of the seagrass Thalassia testudinum, implying no visible negative effects of the presence of the drift algae on the seagrass beneath it (E. A. Irlandi pers. obs.). This observation prompted several questions regarding interactions among drift algae, epiphytes, and seagrass in this subtropical estuary. (1) Does the presence of drift algae, under relevant time frames of algal cover, affect shoot density and/or biomass of $T$. testudinum? (2) Does the presence of drift algae affect short-term growth rates of $T$. testudinum? (3) Is there a negative effect of epiphytes on growth of $T$. testudinum? (4) Does the presence of drift algae reduce epiphyte loads on seagrass leaves as suggested by preliminary observations?

In addressing the first question, it is important to consider the potential impact that the duration of algal cover could have on the underlying seagrass. Previous studies have indicated that seagrass biomass is reduced when algal cover is persistent for extended periods of time (e.g. 6 mo or more, Holmquist 1997). We hypothesized that if algal cover is short in duration it may be beneficial to Thalassia testudinum through the removal of epiphytes, but if algal cover is prolonged it could reduce seagrass biomass and result in mortality. In order to determine the duration of algal cover we measured residence times of drift algae at multiple study sites and examined the effects of drift algal cover on seagrass biomass and shoot density using relevant estimates of the duration of drift algal cover. To approach the second question we measured short-term growth rates (over $1 \mathrm{wk}$ periods) of T. testudinum with and without drift algal cover. The third question was approached using growth studies on seagrass plants with and without 2 types of epiphytes, encrusting calcareous forms and filamentous forms. The fourth question was addressed by comparing epiphyte loads on seagrass blades in the presence and absence of drift algae. The combined studies allowed us to examine interactions among epiphytes, drifting macroalgae, and seagrass in a subtropical estuary.

\section{MATERIALS AND METHODS}

Study region. Biscayne Bay is a subtropical estuary on the southeast coast of Florida, USA. It extends more than $80 \mathrm{~km}$ from north to south and is composed of subbasins with different hydrographic characteristics and drainage basins. All of the sites used in this study, except Barnes Sound, were located in the well-flushed, central region of the bay (Fig. 1). Thalassia testudinum

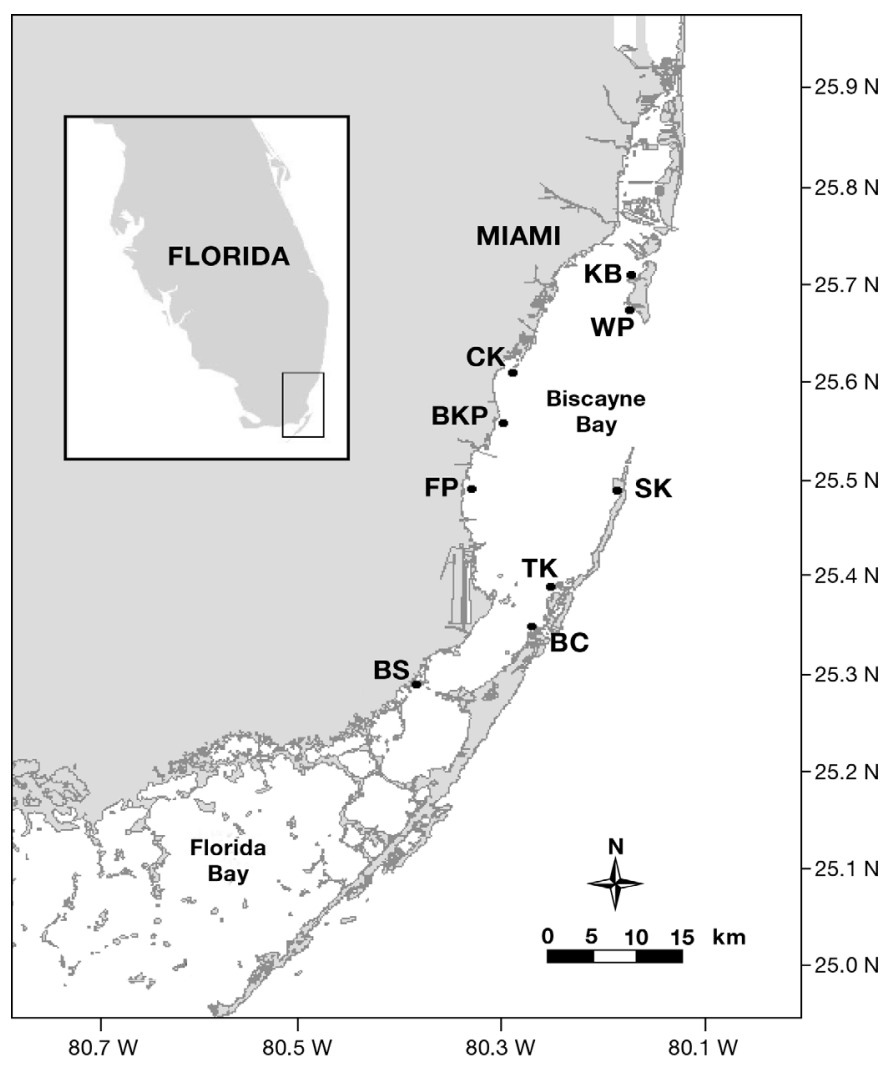

Fig. 1. Location of study sites used in various experiments examining drift algae-epiphyte-seagrass interactions in Biscayne Bay, Florida. KB: Key Biscayne, CK: Chicken Key, WP: West Point, BKP: Black Point, SK: Sands Key, FP: Fender Point, BC: Broad Creek, TK: Totten Key, BS: Barnes Sound 
beds of similar depth range ( 0.5 to $1.0 \mathrm{~m}$ in depth) and encompassing a range of environmental conditions (salinity, nutrient regime, flow) were chosen to evaluate the drift algae-epiphyte-seagrass interactions. Fender Point and Black Point are located on the western side of the bay near canal discharge points (potential source of nutrients and fluctuating salinity), Chicken Key and Barnes Sound are also on the western side of the bay and experience reduced salinities and nutrient inputs due to run off, but there is no direct canal discharge in either vicinity. On the eastern side of the bay several sites (Sands Key, Broad Creek, Key Biscayne, West Point, Totten Key) were chosen that have relatively high and stable salinities and are distant from nutrient sources derived from the mainland. Current flows and wave exposure from wind waves are variable among sites. Qualitative measures of relative water motion using dissolution of chalk blocks indicated that Broad Creek, Black Point, Key Biscayne and Sands Key experience the greatest water motion; Totten Key and West Point experience an intermediate energy regime, and Chicken Key, Fender Point, and Barnes Sound experience less water movement from currents and waves than any of the other study sites (E. A. Irlandi unpubl. data). A complete description of the physical characteristics of each site, along with an ecological model incorporating the influence of these physical parameters on the distribution and abundance of drift algae in Biscayne Bay, are presented in Biber (2002).

Determination of abundance and residence time of drift algae. In order to determine the residence time and movement of algae over a pre-set area of sea floor, we established 5 permanent, $25 \mathrm{~m}$ long transect lines, $5 \mathrm{~m}$ apart at 8 study sites (Key Biscayne, West Point, Chicken Key, Fender Point, Black Point, Sands Key, Broad Creek, Totten Key) (Fig. 1). Each transect line was marked with a sub-water-surface PVC pole at either end, and a weighted polypropylene line ran along the sea floor connecting the 2 poles. We established 8 randomly positioned $0.25 \mathrm{~m}^{2}$ permanent quadrats along each transect line. Over a 1 yr time period (starting September 1997), half of these quadrats were cleared of drift algae on a monthly basis and the other half were not. Prior to establishing a monthly sampling interval we monitored pilot plots with drift algae over daily and weekly time intervals to determine a reasonable sampling period. Given the amount of time required to visit all 8 sites and the results of pilot sampling at shorter time intervals, we concluded that a monthly interval would be sufficient to capture the long-term dynamics of algal cover in the seagrass beds.

At each monthly visit we determined the percentage cover of drift algae in all of the $0.25 \mathrm{~m}^{2}$ marked plots.
Percentage cover estimates were made by counting the number of $10 \times 10 \mathrm{~cm}$ cells within the $0.25 \mathrm{~m}^{2}$ quadrat that contained drift algae and dividing that number by the total number of cells (25). Half of the plots were randomly selected and then cleared of algae. These same plots remained 'cleared' plots and at all subsequent visits percentage cover of drift algae was determined and the plots were re-cleared. This procedure allowed us to evaluate movement of algae within and into a site. To evaluate duration of algal cover in permanent plots, we determined the percentage cover of the remaining plots (without clearing) at each monthly sampling. We also noted the presence or absence of algae and algal biomass (for quadrats that contained algae) from 10 replicate $0.25 \mathrm{~m}^{2}$ quadrats located haphazardly outside of the transect area at each site at monthly intervals.

The average percentage cover of algae in the permanent, uncleared quadrats and the occurrence and biomass of the haphazardly located $0.25 \mathrm{~m}^{2}$ quadrats were determined each mo at each study site to quantify drift algal abundance. Since the relevant question in terms of drift algal effects on seagrass relates to how long a particular location remained covered with algae, and not necessarily what the average percentage cover for several plots over time was, we also examined the percentage cover data for each of the permanently marked plots for each mo at the 4 sites that had high amounts of algal cover, to assess spatial and temporal patterns in drift algal cover. The percentage cover data from the cleared quadrats were also examined to assess the movement and/or growth of algae, spatially and temporally, over the sampling period.

Effect of drift algae on seagrass density and biomass. We assessed the impact of long-term cover (up to $6 \mathrm{mo}$ ) on seagrass biomass (above and below ground) and shoot density at Chicken Key (Fig. 1) starting in the fall of 1998. Throughout the experiment very little naturally occurring drift algae was observed at the site. We set up sixty $0.25 \mathrm{~m}^{2}$ plots and added approximately $500 \mathrm{~g}$ wet weight (average dry weight ca. $53 \mathrm{~g}$ ) of drift algae (primarily Laurencia spp., a branching alga) to them to obtain $100 \%$ algal cover. Plots were checked periodically to make sure algal cover remained in place over the duration of the study. If necessary, additional algae were added to maintain $100 \%$ algal cover in the plots. Ten of the 60 plots were randomly selected at monthly intervals over a 6 mo period and a $20 \mathrm{~cm}$ diameter $\times 30 \mathrm{~cm}$ deep core was collected from the center of each plot. An additional 10 cores were collected randomly from outside the algae-covered plots to serve as controls. Control cores were collected at a minimum distance of $2 \mathrm{~m}$ from any treatment plot.

All response variables (above- and below-ground biomass, and shoot density) were analyzed via sepa- 
rate 2-way ANOVAs with time (sampling month) and algal cover (with or without) as the independent variables. For this and all subsequent ANOVAs, heteroscedasticity of error variances was tested using an $F_{\max }$ test $(\alpha=0.05)$ prior to analyses, and appropriate transformations were performed when necessary. Tukey's HSD post hoc analyses were used in all cases where significant main effects were detected to further identify treatments that differed significantly from each other.

Effect of drift algae on seagrass growth. We conducted several field experiments to assess the impact of drift algal cover on Thalassia testudinum growth. We established 12 enclosures (in April) with and without drift algae in T. testudinum meadows in Barnes Sound (Fig. 1). The enclosures were $1.2 \mathrm{~m}$ tall and $0.6 \mathrm{~m}$ in diameter $\left(0.28 \mathrm{~m}^{2}\right)$, and were constructed from $10 \times 5 \mathrm{~cm}$ mesh galvanized fencing material that was anchored in place with rebar poles. At the time of the experiment the entire site was covered with drift algae (primarily Laurencia spp. and Polysiphonia spp., both branching forms) with biomass exceeding $140 \mathrm{~g}$ dry weight $\mathrm{m}^{-2}$ and cover of $100 \%$. We removed algae from 6 of the enclosures and left the algal cover intact in the remaining 6 enclosures, thus making this essentially a drift algae removal experiment. The enclosures served to keep algae within plots as well as out of plots that were intended to be free of drift algae. We marked a single shoot for growth in the center of each enclosure using standard leaf marking techniques (Short \& Duarte 2001), and recovered the marked shoots after 10 d. Leaves were marked for growth by passing a needle through the shoot just above the sheath to produce identifiable holes in the blades. Since leaf age influences growth, we standardized growth measurements by determining the maximum, daily, leafelongation or growth rate for each shoot. We did this by measuring the distance (in $\mathrm{mm}$ ) between the hole created by the needle on the fastest growing leaf (typically the youngest) and the hole on the outermost leaf (the oldest and slowest growing leaf used as a reference) (Short \& Duarte 2001).

Additional growth experiments were conducted to further assess the effect of drift algae on growth of Thalassia testudinum by adding algal cover to a seagrass bed that had very little drift algae present at the time of the study (West Point study site in October). Twenty enclosures were established as described above. We added algae to half of the enclosures to achieve $100 \%$ algal cover, and a single shoot per enclosure was marked for determination of maximum daily growth rates over $10 \mathrm{~d}$. Maximum daily growth rates from both experiments (algal removal and algal addition) were analyzed via separate 1-way ANOVAs with algal cover as the independent variable.
Effect of calcareous epiphytes on seagrass growth. We examined the effect of epiphytes on seagrass growth at Broad Creek during a spring season (April). The seagrass blades at this location were covered with calcareous encrusting epiphytes. We removed epiphytes from Thalassia testudinum leaves by scraping the leaves with our fingers (Kendrick \& Lavery 2001), and shoots were marked for growth using standard leaf marking techniques outlined above (Short \& Duarte 2001). Twelve control (unscraped) and 12 scraped shoots were haphazardly located with a minimum of $2 \mathrm{~m}$ between shoots, and a marker buoy was placed near each to aid in relocation. Marked plants were retrieved after $10 \mathrm{~d}$ and maximum daily growth rates were determined as described above.

Epiphyte loads were quantified by scraping epiphytes off the harvested shoots at the end of the experiment and determining epiphyte to shoot weight ratios. Epiphyte weight was standardized to shoot weight to compensate for differences in epiphyte biomass among shoots that could be attributable to differences in amount of available seagrass surface for attachment.

Seagrass growth and epiphyte to seagrass biomass ratios for both scraped and unscraped treatments were analyzed using separate 1-way ANOVAs.

Drift algae-epiphyte-seagrass interactions. We attempted to anchor drift algae over the epiphyteencrusted blades at Broad Creek, but moderately high flow conditions prevented the maintenance of drift algal patches. Instead we used a site with lower current flows (West Point) where epiphytes were present, but where drift algae did not occur at the time of the study. The epiphytes at this location, however, were not the same encrusting calcareous forms seen at Broad Creek. Instead the epiphytes were small branching algae (e.g. Ceramium spp.) growing attached to the seagrass. Flocculent material trapped by the algal epiphytes was also present, and disturbing the plants resulted in dislodgment of much of the epiphyte biomass and associated material.

To examine the effect of epiphytes on seagrass growth and determine the influence of drift algal cover on epiphyte loads we established 10 replicates of each of 3 different treatments in $0.25 \times 0.25 \mathrm{~m}$ plots at West Point in October 1996: addition of drift algae, removal of epiphytes by scraping, and unscraped seagrass leaves (controls). We marked a single shoot in the center of each plot for growth and evaluated growth rates and epiphyte loads at the end of the $7 \mathrm{~d}$ experiment for each shoot. In addition, we quantified background epiphyte loads from 25 haphazardly collected shoots. This was done to determine epiphyte loads of shoots that had not been handled, since loss of epiphytes was apparent in shoots marked for growth (see 'Results' below). Since handling the shoots inadvertently re- 
moved epiphytes, we also collected 15 unmarked seagrass shoots that had been under drift algae for $1 \mathrm{wk}$ and 15 unmarked shoots that had not been covered to assess the impact of drift algae on epiphyte loads.

A 1-way ANOVA was employed to determine the effects of the 3 experimental treatments (addition of drift algae, removal of epiphytes, unscraped controls) on daily growth rates. In addition, epiphyte to seagrass biomass ratios were analyzed via 1-way ANOVAs to compare epiphyte loads at the end of the growth experiment, and to quantify the effects of drift algae on epiphyte loads of unmarked shoots. All error terms given are \pm 1 standard error unless indicated otherwise.

\section{RESULTS}

\section{Determination of abundance and residence time of drift algae}

The average percentage cover of algae in the permanent quadrats varied over space and time (Table 1). Several of the sites showed consistently low algal coverage (e.g. $<5 \%$ for Chicken Key, Broad Creek, Sands Key) (Table 1) that corresponded to low occurrence of algae and low biomass from the quadrats taken outside of the transect area (Table 2). Coverage of algae at Totten Key was $<5 \%$ in all months except May when the mean cover of algae was $10.5 \%( \pm 3.98)$. Black Point and Fender Point showed moderate coverage of algae in September (ca. 13 to $22 \%$ cover), but declined in November and December to $<5 \%$ and remained relatively low until May/June when cover increased again to ca. $20 \%$ (Table 1). West Point demonstrated low coverage $(<2 \%)$ until February when cover of algae increased to $13 \%( \pm 4.11)$, followed by a peak in March of $46.75 \%( \pm 8.31)$ and subsequent decline to less than
$10 \%$ by May and June. The Key Biscayne site showed peak abundance in November and December at ca. $20 \%$ algal cover, with ranges over the rest of the sampling period falling mostly between 5 and $10 \%$ cover (Table 1). These data show that, on average, permanently marked areas experienced algal cover in excess of $20 \%$ for periods of only 1 to 2 mo at a time. In addition, only 1 sampling site had algal cover exceeding $30 \%$ but, similar to the other sites, this level of cover did not persist for more than 2 consecutive mo.

Percentage cover data for each of the permanently marked plots, for each month at the 4 sites that had high amounts of algal cover, indicate that the abundance of algae in specific $0.25 \mathrm{~m}^{2}$ areas changed over time, and the majority of the plots did not experience high algal cover for periods longer than 2 to 3 mo (Fig. 2a-d). The pattern of percentage cover from the cleared quadrats shows that movement of algae within sites was limited (Table 3 ). On average less than 5 to $10 \%$ of the cleared areas became covered with algae in a 1 mo period. The data from Key Biscayne and West Point suggest that episodic events can occasionally result in movement of drift algae to a site or that growth of drift algae occurred within a site. The biomass estimates from the 10 haphazardly collected quadrats and percentage cover data from the permanent quadrats also show that there was an influx or proliferation of algae within these sites in November and December (Key Biscayne) and February (West Point) (Tables 1 \& 2).

\section{Effect of drift algae on seagrass density and biomass}

Shoot density varied over time, ranging from a low of $20.0( \pm 1.36)$ to a high of $32.7( \pm 2.09)$ shoots per core, but there was no effect of algal cover on shoot density

Table 1. Average percentage cover of drift algae in permanently marked $0.25 \mathrm{~m}^{2}$ plots $(\mathrm{n}=20)$ during each sampling month for each of 8 sites in Biscayne Bay, Forida. Plots were not cleared after assessment of percentage cover each month. Numbers in parentheses represent $\pm 1 \mathrm{SE}$

\begin{tabular}{|c|c|c|c|c|c|c|c|c|c|c|}
\hline Month & Chicken Key & Black Point & Fender & r Point & Broad Creek & Totten Key & Sands Key & Key Biscayne & West & t Point \\
\hline Sep & $(0)$ & $22.3 \quad(5.78)$ & 13.15 & $(2.7)$ & $(0)$ & $6.5 \quad(4.35)$ & $(0)$ & $8.2 \quad(2.7)$ & 0 & $(0)$ \\
\hline Oct & (0) & $4.45(1.76)$ & 8.65 & $(2.45)$ & $1.2 \quad(1.2)$ & $1.7 \quad(0.85)$ & (0) & 3.85 (1.87) & 0.9 & $(0.75)$ \\
\hline Nov & (0) & $2.2 \quad(0.93)$ & 3.84 & $(1.54)$ & $0.9 \quad(0.9)$ & $0.5 \quad(0.34)$ & $1.95(0.98)$ & $21.84(6.12)$ & 1.15 & $(0.87)$ \\
\hline Dec & $0.25(0.25)$ & $1.35(0.57)$ & 3.2 & $(1.17)$ & (0) & $2.45(1.94)$ & $1.1 \quad(0.45)$ & $20.75(3.24)$ & 1.1 & (5.97) \\
\hline Jan & $0.05(0.05)$ & $1.25(0.58)$ & 4.05 & (1.70) & $2.75(2.75)$ & $1.95(1.78)$ & $0.85(0.75)$ & $4.45(1.84)$ & 1.9 & $(1.16)$ \\
\hline Feb & $0 \quad(0)$ & $1.65(0.92)$ & 5.85 & (1.90) & $0 \quad(0)$ & $3.75(3.6)$ & (0) & $0.55(0.40)$ & 13.6 & $(4.11)$ \\
\hline Mar & $0.05(0.05)$ & $2.25(0.98)$ & 7.45 & $(2.42)$ & $2.25(2.05)$ & $2.35(2.25)$ & (0) & $1.25(0.56)$ & 46.75 & $(8.31)$ \\
\hline Apr & $0.3 \quad(0.3)$ & $7.3 \quad(4.10)$ & 7.0 & $(2.01)$ & $5.0 \quad(2.93)$ & $1.35(1.25)$ & $1.0 \quad(0.45)$ & $7.00(1.86)$ & 30.8 & $(7.45)$ \\
\hline May & $0.65(0.38)$ & $19.55(7.48)$ & 22.4 & (3.91) & $0.15(0.15)$ & 10.5 & $0.35(0.18)$ & $8.95(2.05)$ & 6.8 & $(3.54)$ \\
\hline Jun & $0.1 \quad(0.1)$ & $9.3 \quad(5.32)$ & 19.1 & $(3.62)$ & $0.6 \quad(0.5)$ & $5.75(2.15)$ & $0.1 \quad(0.07)$ & $9.9 \quad(1.65)$ & 6.8 & $(3.54)$ \\
\hline Jul & (0) & 10.4 & 10.6 & (2.48) & $0.75(0.57)$ & $2.7 \quad(1.84)$ & $0.3 \quad(0.3)$ & 4.25 (1.31) & 0.1 & $(0.1)$ \\
\hline Aug & (0) & 13.2 & 15.4 & (3.84) & $0.55(0.26)$ & $4.15(2.11)$ & (0) & $2.45(0.77)$ & 0.4 & $(0.17)$ \\
\hline
\end{tabular}


Table 2. Mean biomass (g dry weight) of algae from $0.25 \mathrm{~m}^{2}$ quadrats at each of the 8 sites in Biscayne Bay, Florida. Numbers in parentheses represent $\pm 1 \mathrm{SE} . \mathrm{n}=$ the number of quadrats out of 10 that had algae in them and were used to estimate biomass

\begin{tabular}{|c|c|c|c|c|c|c|c|c|}
\hline Month & Chicken Key & Black Point & Fender Point & Broad Creek & Totten Key & Sands Key & Key Biscayne & West Point \\
\hline Sep & $\begin{array}{l}0 \quad(0) \\
n=0\end{array}$ & $\begin{array}{c}6.89(1.34) \\
\mathrm{n}=10\end{array}$ & $\begin{array}{c}6.74(1.65) \\
\mathrm{n}=10\end{array}$ & $\begin{array}{c}0 \quad(0) \\
n=0\end{array}$ & $\begin{array}{c}24.62(0) \\
n=1\end{array}$ & $\begin{array}{c}0 \quad(0) \\
n=0\end{array}$ & $\begin{array}{c}8.59(2.78) \\
\mathrm{n}=10\end{array}$ & $\begin{array}{c}0 \quad(0) \\
n=0\end{array}$ \\
\hline Oct & $\begin{array}{ll}0 & (0) \\
& n=0\end{array}$ & $\begin{array}{c}6.93(1.51) \\
\mathrm{n}=6\end{array}$ & $\begin{array}{c}5.24(1.65) \\
\mathrm{n}=8\end{array}$ & $\begin{array}{c}0 \quad(0) \\
n=0\end{array}$ & $\begin{array}{c}0 \quad(0) \\
n=0\end{array}$ & $\begin{array}{c}0 \quad(0) \\
n=0\end{array}$ & $\begin{array}{c}0.92(0.14) \\
\mathrm{n}=3\end{array}$ & $\begin{array}{c}0 \quad(0) \\
n=0\end{array}$ \\
\hline Nov & $\begin{array}{c}0.007(0) \\
n=1\end{array}$ & $\begin{array}{c}2.32(0.77) \\
\mathrm{n}=8\end{array}$ & $\begin{array}{c}3.92(2.23) \\
\mathrm{n}=2\end{array}$ & $\begin{array}{c}0 \quad(0) \\
\mathrm{n}=0\end{array}$ & $\begin{array}{l}9.34(3.96) \\
\mathrm{n}=4\end{array}$ & $\begin{array}{c}0.06(0) \\
\mathrm{n}=1\end{array}$ & $\begin{array}{l}7.72(2.06) \\
\mathrm{n}=7\end{array}$ & $\begin{array}{c}8.88(3.84) \\
n=5\end{array}$ \\
\hline Dec & $\begin{array}{l}0 \quad(0) \\
\mathrm{n}=0\end{array}$ & $\begin{array}{c}4.03(2.62) \\
\mathrm{n}=2\end{array}$ & $\begin{array}{l}6.59(4.44) \\
\mathrm{n}=5\end{array}$ & $\begin{array}{c}0 \quad(0) \\
n=0\end{array}$ & $\begin{array}{c}0 \quad(0) \\
\mathrm{n}=0\end{array}$ & $\begin{array}{c}2.20(1.47) \\
\mathrm{n}=3\end{array}$ & $\begin{array}{c}9.43(4.65) \\
\mathrm{n}=4\end{array}$ & $\begin{array}{c}4.65(1.97) \\
\mathrm{n}=6\end{array}$ \\
\hline Jan & $\begin{array}{c}0 \quad(0) \\
n=0\end{array}$ & $\begin{array}{l}3.29(1.76) \\
n=5\end{array}$ & $\begin{array}{l}9.35(3.49) \\
\mathrm{n}=5\end{array}$ & $\begin{array}{c}0 \quad(0) \\
\mathrm{n}=0\end{array}$ & $\begin{array}{l}2.31(1.02) \\
\mathrm{n}=4\end{array}$ & $\begin{array}{c}1.27(1.14) \\
\mathrm{n}=4\end{array}$ & $\begin{array}{l}5.89(2.97) \\
\mathrm{n}=5\end{array}$ & $\begin{array}{c}6.35(2.14) \\
\mathrm{n}=5\end{array}$ \\
\hline Feb & $\begin{array}{c}6.16 \quad(0.71) \\
n=2\end{array}$ & $\begin{array}{c}0.99(0) \\
n=1\end{array}$ & $\begin{array}{c}12.64(3.27) \\
n=6\end{array}$ & $\begin{array}{c}0 \quad(0) \\
\mathrm{n}=0\end{array}$ & $\begin{array}{c}0 \quad(0) \\
\mathrm{n}=0\end{array}$ & $\begin{array}{c}0 \quad(0) \\
n=0\end{array}$ & $\begin{array}{c}0 \quad(0) \\
\mathrm{n}=0\end{array}$ & $\begin{array}{c}2.40(0.45) \\
n=8\end{array}$ \\
\hline Mar & $\begin{array}{c}0.402(0.15) \\
\mathrm{n}=2\end{array}$ & $\begin{array}{c}3.63(2.34) \\
\mathrm{n}=2\end{array}$ & $\begin{array}{l}7.94(3.83) \\
\mathrm{n}=5\end{array}$ & $\begin{array}{c}0 \quad(0) \\
\mathrm{n}=0\end{array}$ & $\begin{array}{l}7.59(5.67) \\
\mathrm{n}=4\end{array}$ & $\begin{array}{c}0 \quad(0) \\
\mathrm{n}=0\end{array}$ & $\begin{array}{c}2.18(0.59) \\
\mathrm{n}=9\end{array}$ & $\begin{array}{c}18.60(3.70) \\
\mathrm{n}=10\end{array}$ \\
\hline Apr & $\begin{array}{l}0 \quad(0) \\
\mathrm{n}=0\end{array}$ & $\begin{array}{c}2.07(1.00) \\
\mathrm{n}=3\end{array}$ & $\begin{array}{c}16.79(6.80) \\
\mathrm{n}=9\end{array}$ & $\begin{array}{c}5.14(3.10) \\
\mathrm{n}=3\end{array}$ & $\begin{array}{l}7.28(2.66) \\
\mathrm{n}=4\end{array}$ & $\begin{array}{c}0.15(0) \\
n=1\end{array}$ & $\begin{array}{c}10.13(2.74) \\
n=8\end{array}$ & $\begin{array}{c}43.35(7.52) \\
\mathrm{n}=10\end{array}$ \\
\hline May & $\begin{array}{c}0.816(0.26) \\
n=3\end{array}$ & $\begin{array}{l}3.94(3.72) \\
\mathrm{n}=3\end{array}$ & $\begin{array}{c}28.45(19.95) \\
\mathrm{n}=4\end{array}$ & $\begin{array}{c}14.70(10.52) \\
\mathrm{n}=5\end{array}$ & $\begin{array}{c}19.69(4.05) \\
\mathrm{n}=10\end{array}$ & $\begin{array}{c}0 \quad(0) \\
\mathrm{n}=0\end{array}$ & $\begin{array}{c}4.13(1.92) \\
\mathrm{n}=10\end{array}$ & $\begin{array}{c}11.27(4.14) \\
\mathrm{n}=8\end{array}$ \\
\hline Jun & $\begin{array}{l}0 \quad(0) \\
\mathrm{n}=0\end{array}$ & $\begin{array}{l}6.78(3.13) \\
\mathrm{n}=9\end{array}$ & $\begin{array}{c}17.69(6.53) \\
\mathrm{n}=10\end{array}$ & $\begin{array}{c}0 \quad(0) \\
\mathrm{n}=0\end{array}$ & $\begin{array}{l}4.71(1.86) \\
\mathrm{n}=4\end{array}$ & $\begin{array}{c}0.08(0) \\
n=1\end{array}$ & $\begin{array}{l}5.41(2.16) \\
\mathrm{n}=6\end{array}$ & $\begin{array}{c}2.83(1.40) \\
n=6\end{array}$ \\
\hline Jul & $\begin{array}{c}0.165(0.02) \\
n=2\end{array}$ & $\begin{array}{l}20.64(19.91) \\
\mathrm{n}=5\end{array}$ & $\begin{array}{c}20.20(9.82) \\
n=7\end{array}$ & $\begin{array}{c}0 \quad(0) \\
\mathrm{n}=0\end{array}$ & $\begin{array}{c}15.72(11.40) \\
\mathrm{n}=6\end{array}$ & $\begin{array}{c}0.69(0.47) \\
\mathrm{n}=3\end{array}$ & $\begin{array}{c}2.06(0.43) \\
\mathrm{n}=8\end{array}$ & $\begin{array}{c}2.53(0.79) \\
\mathrm{n}=9\end{array}$ \\
\hline Aug & $\begin{array}{l}0 \quad(0) \\
\mathrm{n}=0\end{array}$ & $\begin{array}{c}28.92(14.24) \\
\mathrm{n}=7\end{array}$ & $\begin{array}{c}10.52(2.77) \\
n=8\end{array}$ & $\begin{array}{c}0 \quad(0) \\
\mathrm{n}=0\end{array}$ & $\begin{array}{c}2.73(0.63) \\
\mathrm{n}=4\end{array}$ & $\begin{array}{c}2.73(0) \\
\mathrm{n}=4\end{array}$ & $\begin{array}{c}0.75(0.06) \\
\mathrm{n}=3\end{array}$ & $\begin{array}{c}0.13(0) \\
n=1\end{array}$ \\
\hline
\end{tabular}

Table 3. Average percentage cover of algae from $0.25 \mathrm{~m}^{2}$ plots $(\mathrm{n}=20)$ at 8 sites in Biscayne Bay, Florida, that were cleared of drift algae (after assessment of \% cover) at monthly intervals. Numbers in parentheses represent $\pm 1 \mathrm{SE}$

\begin{tabular}{|c|c|c|c|c|c|c|c|c|c|c|c|c|c|}
\hline \multirow{2}{*}{$\frac{\text { Month }}{\text { Sep }}$} & \multicolumn{2}{|c|}{ Chicken Key } & Black Point & Fender Point & \multicolumn{2}{|c|}{ Broad Creek } & \multicolumn{2}{|c|}{ Totten Key } & \multicolumn{2}{|c|}{ Sands Key } & Key Biscayne & \multicolumn{2}{|c|}{ West Point } \\
\hline & 0 & $(0)$ & $3.6 \quad(0.92)$ & $8.1 \quad(1.27)$ & 0 & $(0)$ & 0 & $(0)$ & & $(0)$ & $5.05(1.67)$ & 0 & $(0)$ \\
\hline Oct & 0.25 & $(0.25)$ & (0) & $1.95(1.60)$ & 1.2 & $(1.00)$ & 1.3 & $(0.72)$ & 0.85 & $(0.38)$ & $1.85(0.88)$ & 0.3 & $(0.3)$ \\
\hline Nov & 0 & (0) & $0.5 \quad(0.27)$ & $2.65(0.50)$ & 0.55 & (0.39) & 0.35 & $(0.26)$ & 1.4 & $(0.38)$ & $21.1 \quad(4.10)$ & 0.15 & $(0.11)$ \\
\hline Dec & 0 & (0) & $0.15(0.15)$ & $2.3 \quad(0.64)$ & 1 & (1.00) & 1.45 & $(0.91)$ & 2.45 & $(1.0)$ & $32.85(6.03)$ & 0.15 & $(0.15)$ \\
\hline Jan & 1.8 & $(1.56)$ & $5.45(2.54)$ & $0.15(0.11)$ & 8.19 & $(4.25)$ & 0 & (0) & 0 & (0) & $9.3 \quad(2.68)$ & 1.4 & (1.10) \\
\hline Feb & 0 & (0) & 3.15 (1.91) & $10.55(2.68)$ & 2.4 & (1.34) & 0 & (0) & 0 & (0) & $2.9 \quad(1.20)$ & 22.35 & $(4.98)$ \\
\hline Mar & 2.2 & $(2.2)$ & $3.4 \quad(2.00)$ & 3.9 & 4.3 & $(3.50)$ & 1.15 & $(0.74)$ & 0 & (0) & $(0.57)$ & 5.95 & (1.97) \\
\hline Apr & 0 & (0) & $2.25(2.15)$ & $7.15(2.50)$ & 3.5 & $(2.10)$ & 0 & (0) & 2.5 & $(0.74)$ & $9.5 \quad(2.25)$ & 34 & (5.0) \\
\hline May & 0.6 & $(0.31)$ & $6.1 \quad(2.73)$ & $19.5(5.56)$ & 1.45 & $(0.79)$ & 7.95 & (4.95) & 0.2 & $(0.17)$ & $8.25(1.60)$ & 9.6 & $(2.40)$ \\
\hline Jun & 0 & (0) & $3.75(2.42)$ & $4.8(1.16)$ & 0.05 & $(0.05)$ & 1.7 & $(0.75)$ & 0.05 & $(0.05)$ & 6.95 (1.99) & 1.4 & $(0.72)$ \\
\hline Jul & 0 & (0) & $1.45(1.0)$ & $5.3 \quad(1.62)$ & 0.35 & $(0.26)$ & 1.4 & $(0.90)$ & 0.10 & $(0.10)$ & $2.7 \quad(0.87)$ & 0.85 & $(0.50)$ \\
\hline Aug & 0 & (0) & $2.4 \quad(1.61)$ & $9.3 \quad(3.17)$ & 0.35 & $(0.30)$ & 2.2 & $(0.78)$ & 0.15 & $(0.11)$ & $0.9 \quad(0.40)$ & 1 & $(0.62)$ \\
\hline
\end{tabular}

(Table 4, Fig. 3a). Above- and below-ground biomass also varied over time with values for both generally increasing over the 6 mo period (Table 4, Fig. 3b,c). Above-ground biomass was ca. $120 \mathrm{~g}$ dry weight $\mathrm{m}^{-2}$ less when drift algae were present than when they were not $\left(433.1 \mathrm{~g} \mathrm{~m}^{-2} \pm 21.7\right.$ vs $310.8 \mathrm{~g} \mathrm{~m}^{-2} \pm 18.8$ in no drift algae and drift algae treatments, respectively), but the effect of algal cover was consistent over time (i.e. there was no interaction between presence or absence of algae and duration of cover) (Fig. 3b). Below-ground biomass did not vary between control plots with no algae and algae-addition plots (Table 4). Below-ground biomass fluctuated over the 6 mo period, but showed a general trend of increased biomass through time in both algae and no algae treatments (Fig. 3c). 

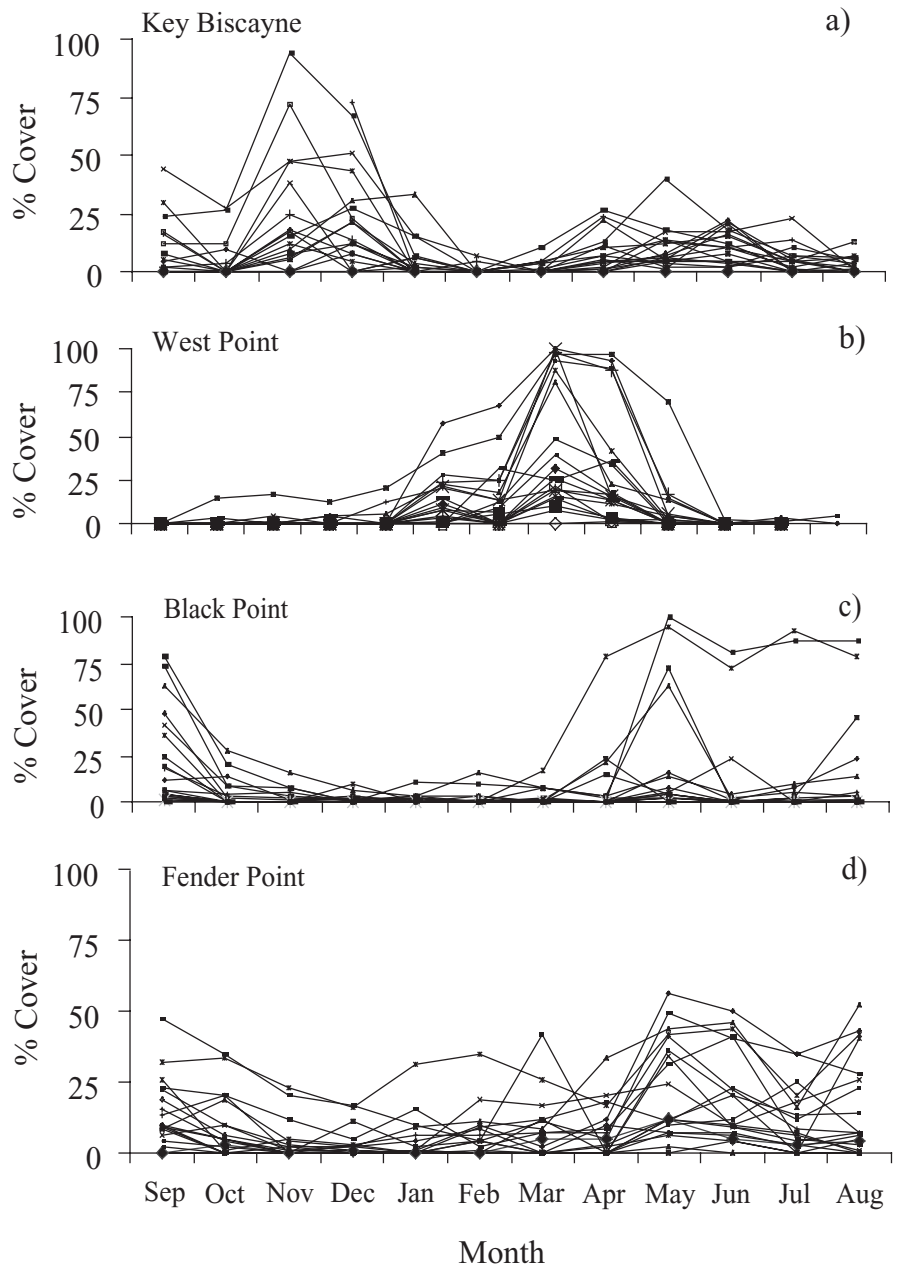

Fig. 2. Monthly percentage cover of drift algae from each of the 20 permanently marked $0.25 \mathrm{~m}^{2}$ plots at (a) Key Biscayne, (b) West Point, (c) Black Point, and (d) Fender Point in Biscayne Bay, Florida, from September 1997 to August 1998

\section{Effect of drift algae on seagrass growth}

Maximum growth rates were not influenced by removal of drift algae $\left(F_{1,14}=0.3198 ; \mathrm{p}=0.5807\right)$ during the spring drift algae removal/seagrass growth experiment. Growth rates were $3.1 \pm 0.52 \mathrm{~mm} \mathrm{~d}^{-1}$ with drift algae present versus $3.5 \pm 0.33 \mathrm{~mm} \mathrm{~d}^{-1}$ with drift algae removed. In addition, there was no effect on Thalassia testudinum growth when drift algae were added to a site in the fall $\left(F_{1,17}=0.0069 ; \mathrm{p}=0.9348\right)$. Growth rates were $5.1 \pm 0.51 \mathrm{~mm} \mathrm{~d}^{-1}$ with drift algae added versus $5.1 \pm 0.32 \mathrm{~mm} \mathrm{~d}^{-1}$ with no drift algae present.

\section{Effect of calcareous epiphytes on seagrass growth}

Epiphyte to seagrass shoot biomass ratios were significantly reduced by our epiphyte removal technique
$(0.334 \pm 0.0523$ with epiphytes vs $0.116 \pm 0.0432$ with epiphytes removed) $\left(F_{1,19}=9.389 ; \mathrm{p}=0.0064\right)$. The epiphyte layer nearly covered the leaves completely and removal significantly increased seagrass growth from $4.1 \pm 0.21 \mathrm{~mm} \mathrm{~d}^{-1}$ for unscraped controls to $5.3 \pm$ $0.53 \mathrm{~mm} \mathrm{~d}^{-1}$ for scraped leaves $\left(F_{1,18}=5.635 ; \mathrm{p}=\right.$ $0.0289)$.

\section{Drift algae-epiphyte-seagrass interactions}

In the second study assessing epiphyte loads, drift algal cover, and daily growth rates of seagrass, growth was not influenced by the presence of drift algae or by removal of epiphytes. The rate of growth was $6.9 \pm$ $0.46 \mathrm{~mm} \mathrm{~d}^{-1}$ with drift algae present, $7.6 \pm 1.12 \mathrm{~mm} \mathrm{~d}^{-1}$ with epiphytes removed, and $8.8 \pm 0.40 \mathrm{~mm} \mathrm{~d}^{-1}$ for controls $\left(F_{2,32}=1.89 ; \mathrm{p}=0.1668\right)$, but interpretation of these results is confounded by the fact that in marking the shoots for growth we inadvertently removed epiphytes as well. This is evidenced by a non-significant difference in epiphyte to seagrass biomass ratios in all cases where shoots were marked for growth (addition of drift algae, $0.087 \pm 0.019$; epiphytes removed, $0.169 \pm 0.024 ;$ unscraped controls, $0.156 \pm 0.0048$ ). Epiphyte to shoot biomass ratios from the haphazardly collected shoots that had not been marked for growth $(0.375 \pm 0.076)$ were, however, significantly higher than the ratios from those that had been under drift algae for $1 \mathrm{wk}(0.087 \pm 0.019)\left(F_{3,56}=4.55 ; \mathrm{p}=0.0063\right)$.

From these results we could not differentiate between the effects of drift algal cover and mechanical disturbance as the causative agent producing reduced

Table 4. Results of 2-way ANOVA on Thalassia testudinum shoot density, above-ground biomass, and below-ground biomass sampled from $20 \mathrm{~cm}$ diameter cores in the center of $0.25 \mathrm{~m}^{2}$ plots, with and without drift algal cover of 1 to $6 \mathrm{mo}$ in duration $(n=10)$

\begin{tabular}{|lrrcc|}
\hline Source & df & MS & $F$ & $\mathrm{p}$ \\
\hline Shoot density & & & & \\
Month & 5 & 452.45 & 7.00 & 0.0001 \\
Algal cover & 1 & 44.08 & 0.682 & 0.4106 \\
Month $\times$ Algae & 5 & 56.87 & 0.880 & 0.4968 \\
Error & 108 & 64.59 & & \\
Above-ground biomass & & & & \\
Month & 5 & 80.36 & 3.579 & 0.0049 \\
Algal cover & 1 & 442.96 & 19.725 & 0.0000 \\
Month $\times$ Algae & 5 & 10.69 & 0.4761 & 0.7934 \\
Error & 108 & 22.46 & & \\
Below-ground biomass & & & & \\
Month & 5 & 425.45 & 10.247 & 0.0000 \\
Algal cover & 1 & 10.88 & 0.262 & 0.6098 \\
Month $\times$ Algae & 5 & 47.61 & 1.147 & 0.3403 \\
Error & 108 & 41.52 & & \\
\hline
\end{tabular}



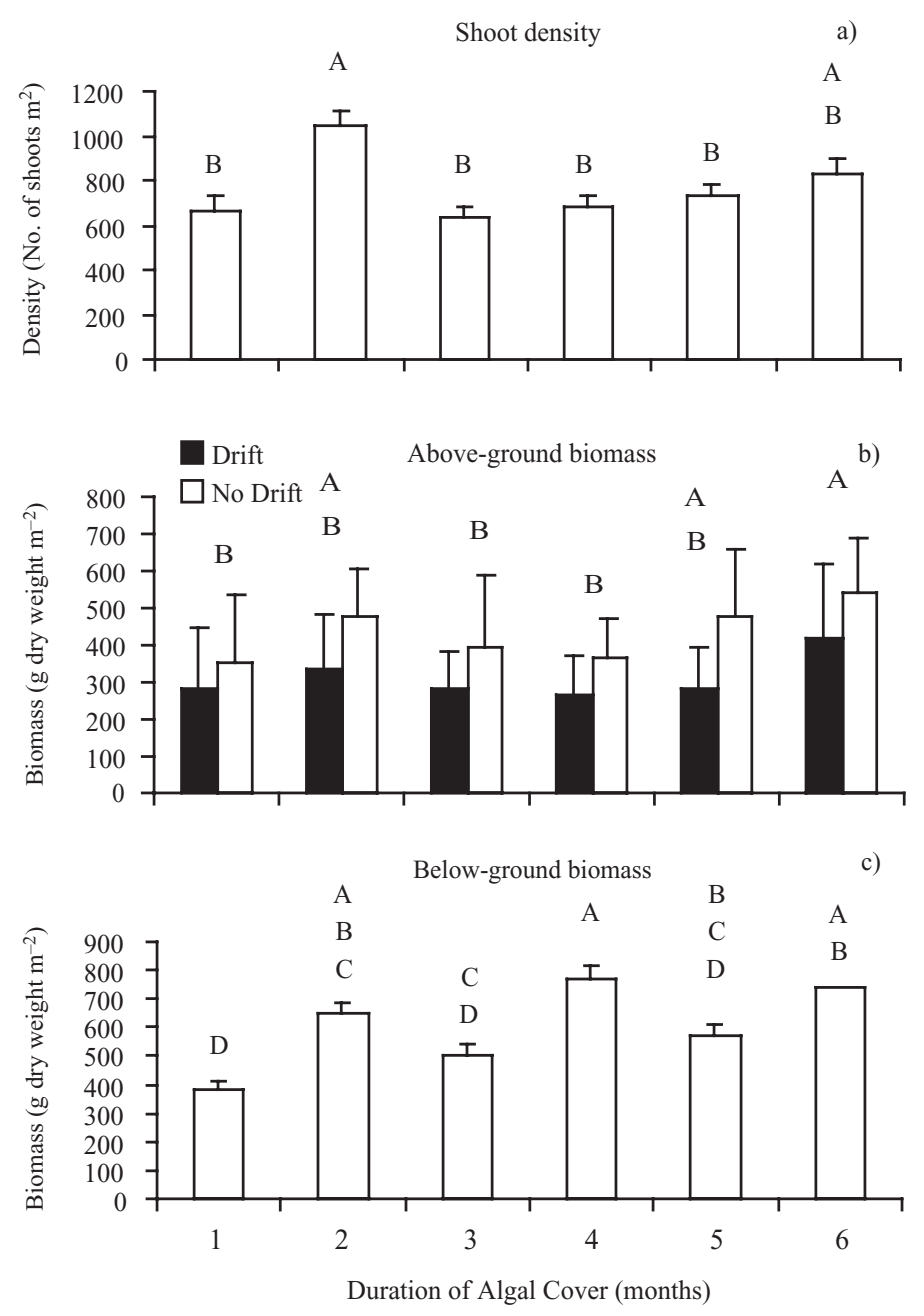

Fig. 3. Thalassia testudinum. (a) Shoot density, (b) aboveground biomass ( $\mathrm{g}$ dry weight $\mathrm{m}^{-2}$ ), and (c) below-ground biomass ( $g$ dry weight $\mathrm{m}^{-2}$ ) from $20 \mathrm{~cm}$ diameter sample cores taken from the center of $0.25 \mathrm{~m}^{2}$ treatment plots. Shoot density and below-ground biomass values are averages from both drift algae and no drift algae treatments. Averages for aboveground biomass are presented from drift algae and no drift algae treatments for each month over 6 mo of sampling. Results of all ANOVAs are presented in Table 4. Error bars represent $+1 \mathrm{SE}$, and different letters denote significant differences among sampling months

epiphyte loads. To confirm the impact of drift algae on epiphyte loads we compared epiphyte to seagrass shoot biomass ratios of unmarked shoots collected from under drift algae to those that were free of drift algal cover. Epiphyte to shoot weight ratios differed significantly between the 2 groups $\left(F_{1,29}=8.37 ; \mathrm{p}=0.007\right)$ with nearly a $50 \%$ reduction in epiphyte to shoot weight ratios (i.e. fewer epiphytes) occurring on seagrass shoots collected from under drift algal cover $(0.126 \pm 0.0219)$ relative to shoots without drift algae (0.242 \pm 0.0352$)$.

\section{DISCUSSION}

Drifting macroalgae and epiphytes are natural components of seagrass communities. When excessive amounts of epiphytes and/or accumulations of drift algae occur, however, there may be negative consequences to the underlying seagrass (Twilley et al. 1985, Holmquist 1997, Valiela et al. 1997, Hauxwell et al. 2001, McGlathery 2001, Nelson \& Lee 2001). Our studies at Broad Creek confirmed in situ decreases in Thalassia testudinum growth in the presence of encrusting calcareous epiphytes, but, in repeated experiments, there was no effect of drift algal cover on growth. In addition, our drift algae studies demonstrated that for several seagrass beds occurring in a well-flushed, subtropical estuary, residence times of drift algae mats were short (ca. 2 to $3 \mathrm{mo}$ ) and percentage cover of algae was relatively low $(<20 \%)$. While experimental maintenance of high drift algal cover $(100 \%)$ for 2 to 3 mo produced a ca. $25 \%$ reduction in above-ground biomass in plots with algal cover compared to plots without, the magnitude of the difference in biomass did not increase with an additional 3 mo of algal cover. In addition, below-ground biomass and shoot density were not affected by the presence of drift algae, suggesting limited long-term negative impacts as root reserves were not depleted. The presence of drifting macroalgae also reduced loads of filamentous epiphytes on seagrass blades suggesting that removal of epiphytes may provide a benefit to seagrass, if epiphyte cover negatively impacts the seagrass.

Seagrass growth can be influenced greatly by light availability (e.g. Dennison \& Alberte 1985, Dennison 1987, Short et al. 1995). Light-levels at the leaf surface can be reduced by the presence of epiphytes and by mats of drift algae, and most studies implicating negative consequences of epiphytes and macroalgae on seagrass invoke decreased light as the primary cause (Sand-Jensen 1977, Silberstein et al. 1986, Short et al. 1995, Holmquist 1997, Hauxwell et al. 2001, Brush \& Nixon 2002). Although we did not quantify light availability, light levels were likely altered by the removal and/or addition of mats of drifting algae. However, when we removed drift algae from plots at a site with widespread algal cover (thus increasing light levels) we saw no increase in shoot growth over $10 \mathrm{~d}$. We also saw no decrease in growth of Thalassia testudinum over a similar time frame when we added $100 \%$ cover of drift algae (thus decreasing light) to plots at a site devoid of algal cover. Both of these studies suggest that increasing or decreasing light availability with the presence of drift algae has no effect on short-term growth of $T$. testudinum. 
Lack of a short-term growth response to drift algal cover may be due to resource sharing between shaded and unshaded short shoots (Tomasko \& Dawes 1989). Other studies have demonstrated limited effects of shading (via shade cloth) on leaf growth of Thalassia testudinum (Tomasko \& Dawes 1989, Czerny \& Dunton 1995, Kraemer \& Hanisak 2000). It is possible that any effects of increasing or decreasing light by removing or adding drift algae to $0.25 \mathrm{~m}^{2}$ plots was masked by resource sharing among shaded and unshaded shoots in the surrounding area.

Interestingly, the removal of encrusting epiphytes (and subsequent increase in light availability at the leaf surface) significantly increased Thalassia testudinum growth in our epiphyte removal study at Broad Creek. The data on the effect of filamentous forms of epiphytes on seagrass growth, however, were inconclusive, due to the confounding effects of inadvertent epiphyte removal while marking shoots for growth. Besides altering light availability (Brush \& Nixon 2002, Brandt \& Koch 2003), epiphyte cover can influence boundary layer dynamics at the leaf surface (SandJensen 1977, Sand-Jensen et al. 1985, Koch 1994). Diatom films and coatings of calcareous algae may inhibit nutrient and/or gas exchange at the leaf surface. Whether or not the increased growth of T. testudinum following removal of calcareous epiphytes was a physiological response to increased light levels or altered boundary-layer dynamics cannot be determined definitively.

While short-term growth rates of Thalassia testudinum were not affected by drift algal cover, the longerterm impacts of prolonged cover on seagrass shoot density and biomass may be of greater consequence. Many factors, including nutrient dynamics, grazing pressure, hydrodynamics, and seasonal fluctuations in light and temperature, will influence the abundance, distribution and persistence of drift algae (Bell \& Hall 1997, Biber 2002). Monthly assessment of percentage cover of algae over permanently marked quadrats at several sites indicated that algal cover generally did not remain high in any specific area (i.e. our $0.25 \mathrm{~m}^{2}$ plots) for extended periods of time in this study (Table 1). The maximum length of time that any single plot was covered with $>30$ to $40 \%$ algal cover was ca. 6 mo, with most not exceeding 2 to 3 mo. Even with $100 \%$ cover of algae for a 6 mo duration, minimal effects were observed on the seagrass beneath it. Aboveground biomass was about $25 \%$ less in plots with 2 to 3 mo of $100 \%$ algal cover compared to plots without algal cover over the same time frame; the magnitude of biomass decline, however, did not increase over time compared to non-covered plots. In addition, shoot density and below-ground biomass were unaffected by the prolonged presence of drift algae (Fig. 3c).
Our results are contrary to an earlier study conducted by Holmquist (1997) in Florida Bay. Unlike the results of our study, those of Holmquist (1997) demonstrated major declines in above- and below-ground biomass and shoot density of Thalassia testudinum in $1 \mathrm{~m}^{2}$ plots after $6 \mathrm{mo}$ of algal cover. In addition, he failed to see recovery of seagrass up to 18 mo after removal of drift algal mats. The cause for the discrepancy between our results and those of Holmquist (1997) is unclear, but it may have been due to differences in plot size and/or the general health of the seagrass meadows being studied. The well-flushed regions of Biscayne Bay have not experienced the same stresses as seagrass beds in Florida Bay where circulation is more restricted. Algal cover may more negatively influence already-stressed plants. Resource sharing in $T$. testudinum may be fairly local extending to within 2 to 3 shoots (Tomasko \& Dawes 1989). It is possible that the shorter distance to adjacent unshaded shoots in $0.25 \mathrm{~m}^{2}$ plots compared to $1 \mathrm{~m}^{2}$ plots may have allowed for more resource sharing.

The amount of drift algal cover at a particular site can be quite varied, ranging from a few small clumps (cm across) that may be widely spaced, to moderately sized clumps (10s of $\mathrm{cm}$ across) spaced closely $(\mathrm{cm})$ or far apart (m), to thick, continuous mats of algae that can cover very large areas for extended periods of time. The extent of cover and size of plots used in this study were within the range of representative drift algal conditions for Biscayne Bay and probably other seagrass systems. A more thorough investigation on the temporal and spatial distribution of drift algal clumps and the subsequent effects of clumps of varying size under different spatial arrangements (e.g. widely spaced versus more continuous cover) on resource sharing, and resultant effects on growth and biomass of the underlying seagrass, would elucidate important scale-related effects of drift algal cover on seagrass.

Differences in plant anatomy among different species of seagrass may also influence the ultimate effect that drift algal cover has on the underlying seagrass. Healthy Thalassia testudinum has a very robust rhizome system (Zieman 1982) that can provide resource reserves allowing continued growth and production during periods of stress. Other species of seagrass with reduced rhizome material, and therefore less stored reserves for use during periods of stress, may be more influenced by light reduction from algal cover. For example, mortality of Halophila ovalis (a species with limited below-ground structure) occurred after $38 \mathrm{~d}$ of shading via shade cloth while Halodule pinifolia (a species with a more developed root-rhizome system) showed no loss of biomass over the same time frame (Longstaff \& Dennison 1999). In addition, accumula- 
tions of macroalgae and associated reductions in light in temperate seagrass meadows have resulted in decreased production and even mortality of Zostera marina (Hauxwell et al. 2001, McGlathery 2001, Nelson \& Lee 2001).

The outcome of the interactions between epiphytes, seagrass, and macroalgae are variable. Epiphytes may provide protection from UV-B radiation (Brandt \& Koch 2003) yet also reduce levels of PAR (Brush \& Nixon 2002) and/or reduce gas exchange at the leaf surface (Sand-Jensen 1977, Sand-Jensen et al. 1985, Koch 1994). The type and degree of epiphyte cover will ultimately determine whether the interaction is positive, negative, or neutral to the underlying seagrass. Prior studies on the effects of macroalgae on seagrass have demonstrated primarily negative impacts (Holmquist 1997, Hauxwell et al. 2001, McGlathery 2001, Nelson \& Lee 2001). As with epiphytes, the type and amount of macroalgal cover may determine the direction of the interaction with seagrass. Densely branching and sheet morphologies that greatly restrict water flow and/or block more light will have a larger impact on water chemistry and light availability than more loosely branching forms, and species that produce toxic secondary metabolites may leach exudates that could influence epiphytes and/or seagrass.

Our study suggests that under moderate cover macroalgae pose limited negative consequences and may actually provide a beneficial effect by removing epiphytes. We could not quantify the effects of drift algae on the calcareous epiphytes due to our inability to maintain mats of drift algae as a result of the high flow at that particular site. Casual observations from other locations, however, reveal cleaner shoots under drift algae in areas with calcareous epiphytes (E. A. Irlandi pers. obs.), and for filamentous forms we confirmed that drift algal cover for as short as a $1 \mathrm{wk}$ period significantly decreases epiphyte loads. The results of our study emphasize the importance of the temporal and spatial dynamics of drift algal cover when assessing impacts on seagrass. Besides providing a means of transport for organisms (Holmquist 1994), movement of drift algae through a seagrass meadow may create patches of reduced epiphytes on seagrass leaves, thus allowing for greater productivity of the underlying seagrass, as long as the algae do not persist for several months. The potential for positive interactions (e.g. Bertness \& Callaway 1994, Bertness \& Hacker 1994) between drift algae and seagrass exists via drift algae reducing epiphyte loads. Further study is needed to determine whether true positive impacts on seagrass occur under different spatial and temporal patterns of algal cover, whether or not it is specific to the species composition of the algal cover, and if the effects are the same with various types of epiphytes.
Acknowledgements. Special thanks to S. Maciá, T. Jones, and L. Kaufman for field assistance and to Biscayne National Park for boat use in support of field work. Appreciation is also extended to the anonymous reviewers and to L. Levin for their comments and editorial review. Their work helped to greatly improve the manuscript. This project was funded by NOAA Coastal Ocean Program Grant \# NA37RJ0149 to M. Harwell and the Center for Marine and Environmental Analyses, University of Miami, Rosenstiel School of Marine and Atmospheric Science.

\section{LITERATURE CITED}

Bell SS, Hall MO (1997) Drift macroalgal abundance in seagrass beds: investigating large-scale associations with physical and biotic attributes. Mar Ecol Prog Ser 147: 277-283

Bertness MD, Callaway R (1994) Positive interactions in communities. Trends Ecol Evol 9:191-193

Bertness MD, Hacker SD (1994) Physical stress and positive associations among marsh plants. Am Nat 144:363-372

Biber PD (2002) The effects of environmental stressors on the dynamics of three functional groups of algae in Thalassia testudinum habitats of Biscayne Bay, Florida: a modeling approach. PhD dissertation, University of Miami, FL

Brandt LA, Koch EW (2003) Periphyton as a UV-B filter on seagrass leaves: a result of different transmittance in the UV-B and PAR ranges. Aquat Bot 76:317-327

Brush MJ, Nixon SW (2002) Direct measurements of light attenuation by epiphytes on eelgrass Zostera marina. Mar Ecol Prog Ser 238:73-79

Coleman VL, Burkholder JM (1994) Community structure and productivity of epiphytic microalgae on eelgrass (Zostera marina L.) under water-column nitrate enrichment. J Exp Mar Biol Ecol 179:29-48

Czerny AB, Dunton KH (1995) The effects of in situ light reduction on the growth of two subtropical seagrasses, Thalassia testudinum and Halodule wrightii. Estuaries 18:418-427

Dennison WC (1987) Effects of light on seagrass photosynthesis, growth and depth distribution. Aquat Bot 27:15-26

Dennison WC, Alberte RS (1985) Role of daily light period in the depth distribution of Zostera marina (eelgrass). Mar Ecol Prog Ser 25:51-61

Duarte CM (1995) Submerged aquatic vegetation in relation to different nutrient regimes. Ophelia 41:87-112

Frankovich TA, Fourqurean JW (1997) Seagrass epiphyte loads along a nutrient availability gradient, Florida Bay, USA. Mar Ecol Prog Ser 159:37-50

Frankovich TA, Zieman JC (1994) Total epiphyte and epiphytic carbonate production on Thalassia testudinum across Florida Bay. Bull Mar Sci 54:679-695

Fry B (1984) ${ }^{13} \mathrm{C} /{ }^{12} \mathrm{C}$ ratios and the trophic importance of algae in Florida Syringodium filiforme seagrass meadows. Mar Biol 79:11-19

Gacia E, Littler MM, Littler DS (1999) An experimental test of the capacity of food web interactions (fish-epiphytesseagrasses) to offset the negative consequences of eutrophication on seagrass communities. Estuar Coast Shelf Sci 48:757-766

Harlin MM (1980) Seagrass epiphytes. In: Phillips R, McCoy CP (eds) Handbook of seagrass biology: An ecosystem perspective. Garland STPM Press, New York, p 117-152

Hauxwell J, McClelland J, Behr PJ, Valiela I (1998) Relative importance of grazing and nutrient controls of macroalgal biomass in three temperate shallow estuaries. Estuaries 21:347-360 
Hauxwell J, Cebrian J, Furlong C, Valiela I (2001) Macroalgal canopies contribute to eelgrass (Zostera marina) decline in temperate estuarine ecosystems. Ecology 82:1007-1022

Heck KL Jr, Pennock JR, Valentine JF, Coen LD, Sklenar SA (2000) Effects of nutrient enrichment and small predator density on seagrass ecosystems: an experimental assessment. Limnol Oceanogr 45:1041-1057

Heijs FML (1987) Community structure and seasonality of macroalgae in some mixed seagrass meadows from Papua New Guinea. Aquat Bot 27:139-158

Herrnkind WF, Butler MJ IV (1986) Factors regulating postlarval settlement and juvenile microhabitat use by spiny lobsters Panulirus argus. Mar Ecol Prog Ser 34:23-30

Holmquist JG (1994) Benthic macroalgae as a dispersal mechanism for fauna: influence of a marine tumbleweed. J Exp Mar Biol Ecol 180:235-251

Holmquist JG (1997) Disturbance and gap formation in a marine benthic mosaic: influence of shifting macroalgal patches on seagrass structure and mobile invertebrates. Mar Ecol Prog Ser 158:121-130

Humm HJ (1964) Epiphytes of the seagrass Thalassia testudinum in Florida. Bull Mar Sci 14:306-341

Kendrick GA, Lavery PS (2001) Assessing biomass, assemblage structure and productivity of algal epiphytes on seagrasses. In: Short FT, Coles RG (eds) Global seagrass research methods. Elsevier, New York, p 199-222

Klumpp DW, Salita-Espinosa JS, Fortes MD (1992) The role of epiphytic periphyton and macroinvertebrate grazers in the trophic flux of a tropical seagrass community. Aquat Bot 43:327-349

Koch EW (1994) Hydrodynamics, diffusion-boundary layers and photosynthesis of the seagrasses Thalassia testudinum and Cymodocea nodosa. Mar Biol 118:767-776

Kraemer GP, Hanisak MD (2000) Physiological growth responses of Thalassia testudinum to environmentallyrelevant periods of low irradiance. Aquat Bot 67:287-300

Kulczycki GR, Virnstein RW, Nelson WGN (1981) The relationship between fish abundance and algal biomass in a seagrass-drift algae community. Estuar Coast Shelf Sci 12: 341-347

Lapoint BE, Tomasko DA, Matzie WR (1994) Eutrophication and trophic state classification of seagrass communities in the Florida Keys. Bull Mar Sci 54:696-717

Lavery PS, Lukatelich RJ, McComb AJ (1991) Changes in the biomass and species composition of macroalgae in a eutrophic estuary. Estuar Coast Shelf Sci 33:1-22

Longstaff BJ, Dennison WC (1999) Seagrass survival during pulsed turbidity events: the effects of light deprivation on the seagrasses Halodule pinifolia and Halophila ovalis. Aquat Bot 65:105-121

McGlathery KJ (1995) Nutrient and grazing influences on a subtropical seagrass community. Mar Ecol Prog Ser 122: 239-252

McGlathery KJ (2001) Macroalgal blooms contribute to the decline of seagrass in nutrient-enriched coastal waters. J Phycol 37:453-456

Neckles HA, Wetzel RL, Orth RJ (1993) Relative effects of nutrient enrichment and grazing on epiphyte-macrophyte (Zostera marina L.) dynamics. Oecologia 93:285-295

Neckles HA, Koepfler ET, Haas LW, Wetzel RL, Orth RJ (1994) Dynamics of epiphytic photoautotrophs and heterotrophs in Zostera marina (eelgrass) microcosms: responses to nutrient enrichment and grazing. Estuaries 17:597-605

Editorial responsibility: Lisa Levin (Contributing Editor), La Jolla, California, USA
Nelson TA, Lee A (2001) A manipulative experiment demonstrates that blooms of the macroalga Ulvaria obscura can reduce eelgrass shoot density. Aquat Bot 71:149-154

Pollard PC, Kogure K (1993) The role of epiphytic and epibenthic algal productivity in a tropical seagrass, Syringodium isoetifolium (Aschers.) Dandy, community. Aust J Mar Freshw Res 44:141-154

Sand-Jensen K (1977) Effects of epiphytes on eelgrass photosynthesis. Aquat Bot 3:55-63

Sand-Jensen K, Revsbach NP, Jorgensen BB (1985) Microprofiles of oxygen in epiphyte communities on submerged macrophytes. Mar Biol 89:55-62

Schneider FI, Mann KH (1991) Species specific relationships of invertebrates to vegetation in a seagrass bed. 1. Correlational studies. J Exp Mar Biol Ecol 145:101-117

Short FT, Duarte CM (2001) Methods for measurement of seagrass growth and production. In: Short FT, Coles RG (eds) Global seagrass research methods. Elsevier, New York, p 155-182

Short FT, Burdick DM, Kaldy JE III (1995) Mesocosm experiments quantify the effects of eutrophication on eelgrass, Zostera marina. Limnol Oceanogr 40:740-749

Silberstein K, Chiffings AW, McComb AJ (1986) The loss of seagrass in Cockburn Sound, Western Australia. III. The effects of epiphytes on productivity of Posidonia australis Hook. F. Aquat Bot 24:355-371

Taylor DI, Nixon SW, Granger SL, Buckley BA, McMahon JP, Lin HJ (1995) Responses of coastal lagoon plant communities to different forms of nutrient enrichment-a mesocosm experiment. Aquat Bot 52:19-34

Tomasko DA, Dawes CD (1989) Evidence for physiological integration between shaded and unshaded short shoots of Thalassia testudinum. Mar Ecol Prog Ser 54:299-305

Tomasko DA, Lapointe BE (1991) Productivity and biomass of Thalassia testudinum as related to water column nutrient availability and epiphyte levels: field observations and experimental studies. Mar Ecol Prog Ser 75:9-17

Twilley RJ, Kemp WM, Staver KW, Stevenson JC, Boynton WR (1985) Nutrient enrichment of estuarine submersed vascular plant communities. 1. Algal growth and effects on production of plants and associated communities. Mar Ecol Prog Ser 23:179-191

Valiela I, McClelland J, Hauxwell J, Behr PJ, Hersh D, Foreman K (1997) Macroalgal blooms in shallow estuaries: controls and ecophysiological and ecosystem consequences. Limnol Oceanogr 42:1105-1118

Virnstein RW, Carbonera PA (1985) Seasonal abundance and distribution of drift algae and seagrasses in the mid-Indian River Lagoon, Florida. Aquat Bot 23:67-82

Virnstein RW, Howard RK (1987) Motile epifauna of marine macrophytes in the Indian River Lagoon, Florida. 2. Comparisons between drift algae and three species of seagrasses. Bull Mar Sci 41:13-26

Wear DJ, Sullivan MJ, Moore AD, Millie DF (1999) Effects of water-column enrichment on the production dynamics of three seagrass species and their epiphytic algae. Mar Ecol Prog Ser 179:201-213

Williams SL, Ruckelshaus MH (1993) Effects of nitrogen availability and herbivory on eelgrass (Zostera marina) and epiphytes. Ecology 74:904-918

Zieman JC (1982) The ecology of the seagrasses of south Florida: a community profile. FWS/OBS $82 / 25$, US Fish \& Wildl Serv, Office of Biological Services, Washington, DC

Submitted: October 7, 2003; Accepted: April 23, 2004

Proofs received from author(s): September 6, 2004 